then be taken to cross-match blood, empty the uterus, give further oxytocics, and repair genital trauma. The report by the Ministry of Health (1963) on maternal deaths in England and Wales for the years 1958-60 emphasized the frequency with which attendants failed to realize the serious state of patients who had bled. Considerable underestimation of the extent of blood loss often contributed to this failure. Of the 742 deaths studied 130 were believed to have haemorrhage as the primary factor leading to death. In 61 of these (31 with avoidable factors) the bleeding was postpartum.

This investigation has shown that in routine hospital praciice there is considerable underestimation of blood loss, and yet this hospital is representative of those with a high standard of antenatal and intranatal care.

The present finding of virtually invariable underestimation, especially when the recorded loss exceeds $300 \mathrm{ml}$., suggests most strongly that unappreciated and underestimated blood loss is a much more important factor in many maternal deaths than available statistics show.

Reports have appeared in which the criterion for assessing the effect of anaesthetic and oxytocic preparations on the third stage of labour has been the incidence of postpartum haemorrhage (Embrey et al., 1963 ; Friedman, 1957 ; McBride, 1954). The findings in this survey suggest that this criterion is of little value unless clinical estimation of blood loss is replaced by accurate measurement.

It is hoped that the present investigation will emphasize to those attending vaginal deliveries how often considerable haemorrhages occur, so that by early action disastrous exsanguinations will be avoided.

\section{Summary}

A method of accurately measuring blood loss is outlined. Blood is extracted in a washing-machine and measured spectro- metrically as oxyhaemoglobin. The bleeding that occurred after 57 vaginal deliveries was measured. When this measured amount was compared with the estimate recorded at the time of delivery the estimate was reasonably correct for small losses. However, when the recorded loss exceeded $300 \mathrm{ml}$. underestimation was invariable, and as the loss became greater so did the amount of underestimation. On the basis of these measurements it is calculated that in over $20 \%$ of vaginal deliveries the blood loss exceeds $500 \mathrm{ml}$. A systolic blood pressure below $100 \mathrm{~mm}$. Hg and a pulse rate above 100 beats per minute are late signs of depleted blood velume and indicate commencing failure of the compensatory mechanisms.

I wish to thank Mr. H. G. Dixon and Mr. W. G. MacGregor for their help and advice; Professor J. C. McClure Browne for permission to study the patients; Miss C. M. Miller and the midwives for their co-operation; Mr. E. Simmonds for technical advice and assistance; Dr. A. G. Hawkes, of the Statistics Department of University College, for assistance in checking the statistical significance of the data; and, finally, the directors of Associated Electrical Industries, Hotpoint Ltd., for their generosity in donating the washing-machine.

REFERENCES

Coller, F. A., Crook, C. E., and Iob, V. (1944). F. Amer. med. Ass.,

Embrey, M. P., Barber, D. T. C., and Scudamore, J. H. (1963). Brit. med. Y., 1, 1387

Friedman, E. A. (1957). Amer. 7. Obstet. Gynec., 73, 1306.

Friedman, E. A. (1957). Amer. f. Obstet. Gynec., 73, 1306. Obstet. and Gynec., 19, 455 .

Gatch, W. D., and Little, W. D. (1924). F. Amer. med. Ass., 83, 1075. Grant, R. T., and Reeve, E. B. (1951). Spec. Rep. Ser. med. Res. Coun. (Lond.), No. 277, p. 3 .

McBride, W. (1954). Med. F. Aust., 1, 118

Ministry of Health (1963). Reports on Public Health and Medical Subiects, No. 108. Report on Confidential Enquiries into Maternal Deaths in England and Wales, 1958-1960, p. 13. London.

Murdoch, R. (1958). Lancet, 2, 731.

Pirdoch, R. (19) Sheard, C (1937). Proc. Mayo Clin., 12, 209.

Pilcher, F., and G. G., Perloff, W. H., and Israel, S. L. (1960). 7. Amer. med. Ass., 172, 20.

Spoevel, W. E., and Heagy, F. C. (1962). Canad. F. Surg., 5, 25.

Thornton, J. A. (1963). Ann. roy. Coll. Surg. Engl., 33, 164.

\title{
Some Factors Affecting Bacterial Colony Counts in Urinary Infection
}

\author{
A. P. ROBERTS,* B.SC. ; R. E. ROBINSON,† F.R.C.S. ; R. W. BEARD, $\ddagger$ M.B., M.R.C.O.G.
}

Brit. med. F., 1967, 1, 400-403

Colony counting is the numerical estimation of the number of viable organisms in a millilitre of uncentrifuged urine. This quantitative estimation enables true bacteriuria to be differentiated from urethral or vulval contamination which may occur when midstream or " clean catch" urine is collected (Marple, 19.1 ; Kass, 1957). A count of more than 100,000 organisms per ml. of urine is generally regarded as diagnostic of infection, although, as Kass (1962) has pointed out, the accuracy of the diagnosis is improved from 80 to $96 \%$ if two consecutive specimens from the same patient are cultured. At the other end of the scale it is thought unlikely that urinary infection is present if the colony count of the midstream urine is less than 10,000 organisms per ml. A colony count between these two levels is thought to signify urine infection in only $5 \%$ of cases. Bradley and Little (1963) have shown that colony counting is superior to semiquantitative assessments of bacteriuria such as

\footnotetext{
* Research Assistant.

Resident Medical Officer.

F Senior Lecturer. London.
}

"heavy" or "scanty" growth, but the danger in the use of colony counts for diagnosis lies in the too rigid adherence to the absolute levels mentioned.

Certain factors, such as the rate of flow of the urine, the amount of vaginal discharge in women, and the method of collection of the midstream specimen, may affect the level of bacteriuria so considerably that occasionally a false-positive or false-negative diagnosis may result. In addition, in routine hospital practice the collection of the midstream specimen is often left to nursing staff who may be inexperienced in the technique, and almost always the diagnosis of urinary infection is made on the result obtained from a single specimen. This is unfortunate, but because of shortage of staff it may be unavoidable. Undoubtedly the ideal method of collecting urine in women, to avoid contamination, is by the suprapubic route, when the finding of even small numbers of organisms in the specimen is evidence of urinary infection (Stamey et al., 1965 ; Beard et al., 1965), but this technique is not always practicable. In this study the extent to which some of thes: factors affect the quantitative assessment of urine infection in a 
midstream specimen of urine has been investigated, and suggestions made for the avoidance of these sources of error.

\section{Methods and Materials}

The majority of patients in this study had been delivered at least eight weeks previously, so that serious contamination of the midstream specimen from vaginal discharge was unlikely. All patients were under investigation for a suspected urinary infection. The possibility that chlorhexidine digluconate (Hibitane) solution, used for vulval swabbing before the midstream urine was collected, might reduce the level of infection was investigated by comparing colony counts from midstream and suprapubic urine. The technique of collecting the midstream urine was that of Wood et al. (1960), which was fully explained by the ward sister to the nurse who was to collect the specimen. The periurethral and vulval areas were swabbed by the nurse with a $1: 2,000$ solution of chlorhexidine and then dried. The patient was instructed to hold her labia apart with her left hand and when micturition had started briefly to pass a wide-mouthed jar into the stream. The urine was sent to the laboratory and cultured within one hour of collection and stored at $4^{\circ} \mathrm{C}$. Suprapubic specimens of urine were taken just before the midstream specimen. A colony count by the serial dilution pour-plate method was done on the uncentrifuged urine. The whole of the ruled area of a Neubauer counting chamber was used for estimating the number of white blood cells in $1 \mathrm{ml}$. of uncentrifuged urine.

To exclude other possible causes for the bacterial inhibition observed in the midstream urine three in-vitro experiments were set up with the sort of dilutions of chlorhexidine which might be expected from contamination of the specimen. A sterile specimen of urine which had been previously Seitzfiltered was divided into four aliquots of $25 \mathrm{ml}$. Each of these was inoculated with the same strain of Escherichia coli obtained from a bacteriuric patient, and incubated at $37^{\circ} \mathrm{C}$. for three hours. A colony count was done on each of the aliquots before a known volume of $1: 2,000$ chlorhexidine was added to three of them. All urines were left to stand at room temperature for three hours, and then refrigerated for a further 21 hours; colony counts were done at each of the stages.

In order to provide a satisfactory alternative to chlorhexidine for vulval swabbing a further study was done on patients who had been delivered at least eight weeks previously. A suprapubic specimen was collected, followed immediately by a midstream specimen after the patient had been prepared exactly as described above except that sterile water was used instead of chlorhexidine solution. Colony counts were done on 50 pairs of specimens.

The effect of an induced diuresis on the colony count was studied. A suprapubic specimen (I) was taken from the patient on waking in the morning. After micturition she was given about 1 litre of water to drink. A further specimen (II) was taken as soon as the bladder was palpable. A colony count was done on both specimens, and the urinary dilution was estimated by measuring the creatinine concentration in each specimen by the modified micromethod of Folin (Folin and Doisy, 1917). Fluctuations in the level of bacteriuria due to variations in flow rates of urine and frequency of micturition during the day were studied in seven pregnant women known to have asymptomatic bacteriuria who were admitted to the hospital as ambulant inpatients for four days. On the first day a suprapubic specimen was taken in the morning, and then all subsequent micturitions were collected as midstream specimens for 48 hours; patients were swabbed with sterile water instead of chlorhexidine for this procedure. For the remaining two days the patients were encouraged to drink up to 3 litres of water a day, and as many midstream urines as possible were collected during this time. Urinary output was measured, and the time of each micturition was recorded. All patients were given a course of sulphonamides on discharge from hospital. A more detailed analysis of these results will be given in a future communication.

\section{Results}

Table I shows the reduction in the colony count which occurred in the midstream as compared with the suprapubic urine in 12 out of 20 women who were swabbed with chlorhexidine before the midstream urine was collected. In the remaining eight cases no reduction in the viable count was observed. In the affected cases, wher the midstream urine was cultured shortly after collection of the specimen some reduction in the colony count was present in all except one instance. In one of these cases the count was reduced from more than 10 million to 20 organisms per $\mathrm{ml}$. The colony count was still further reduced in eight out of nine of the refrigerated midstream urines, though there was no change in the level of infection in the suprapubic specimens. In five of these cases the colony counts, which were considerably in excess of 100,000 organisms per ml. in the suprapubic urine, were reduced well below this level in the midstream urine, and in one case the midstream urine was sterile. This particular urine proved to be bactericidal to an inoculum of an actively growing strain of $E$. coli, providing further evidence that the midstream urine had been contaminated with some strongly inhibitory substance.

Comparison of white blood cell counts in suprapubic and midstream urine in Table I shows that the level is consistently higher in the midstream specimen. Table II is an example of the very small amounts of chlorhexidine required to reduce the colony counts when it is added to infected urine. In the other two experiments a reduction in the colony count occurred in culture 1 , to which $4 \mu \mathrm{l}$. of $1: 2,000$ chlorhexidine per ml. had been added, though bacterial growth was not inhibited in cultures 2 and 3 .

TaBle I.-Comparison of Bacterial Colony and White Blood Cell Counts in Midstream and Suprapubic Urine. Midstream Urines were Collected after Vulval Swabbing with a $1: 2,000$ Solution of Chlorhexidine

\begin{tabular}{|c|c|c|c|c|c|}
\hline & \multirow{2}{*}{$\begin{array}{c}\text { Urine } \\
\text { Collection-Culture } \\
\text { Time }\end{array}$} & \multicolumn{2}{|c|}{ Colony Count/ml. Urine } & \multirow{2}{*}{$\frac{\text { W.B.C./ml }}{\text { Suprapubic }}$} & \multirow{2}{*}{ 1. Urine } \\
\hline & & Suprapubic & Midstream & & \\
\hline E. coli & $\begin{array}{l}<1 \text { hour } \\
24 \text { hours at } 4^{\circ} \mathrm{C} .\end{array}$ & $\begin{array}{l}840,000 \\
710,000\end{array}$ & $\begin{array}{r}36,000 \\
9,000\end{array}$ & 4,000 & 22,000 \\
\hline ” & $\begin{array}{l}<1 \text { hour } \\
24 \text { hours at } 4^{\circ} \mathrm{C} \text {. }\end{array}$ & $\begin{array}{l}1,760,000 \\
1,960,000\end{array}$ & $\begin{array}{r}830,000 \\
37,000\end{array}$ & 0 & 0 \\
\hline " & $\begin{array}{l}<1 \text { hour } \\
72 \text { hours at } 4^{\circ} \mathrm{C} \text {. }\end{array}$ & $\begin{array}{r}550,000 \\
630,000\end{array}$ & $\begin{array}{r}175,000 \\
920\end{array}$ & 6,000 & 39,000 \\
\hline & $\begin{array}{l}<1 \text { hour } \\
72 \text { hours at } 4^{\circ} \mathrm{C} \text {. }\end{array}$ & $\begin{array}{l}>10^{7} \\
>10^{7}\end{array}$ & $\begin{array}{r}1,580,000 \\
140,000\end{array}$ & 31,000 & 105,000 \\
\hline " " & $\begin{array}{l}<1 \text { hour } \\
72 \text { hours at } 4^{\circ} \mathrm{C} \text {. }\end{array}$ & $\begin{array}{l}5,740,000 \\
6,200,000\end{array}$ & $\begin{array}{r}1,240,000 \\
67,000\end{array}$ & 19,000 & 74,000 \\
\hline " " & $\begin{array}{l}<1 \text { hour } \\
24 \text { hours at } 4^{\circ} \mathrm{C} \text {. }\end{array}$ & $\begin{array}{l}3,400 \\
4,500\end{array}$ & $\begin{array}{l}2,600 \\
1,600\end{array}$ & 0 & 0 \\
\hline $\left.\begin{array}{c}\text { Strepto- } \\
\text { coccus }\end{array}\right\}$ & $\begin{array}{l}<1 \text { hour } \\
24 \text { hours at } 4^{\circ} \mathrm{C} \text {. }\end{array}$ & $\begin{array}{l}>10^{7} \\
>10^{7}\end{array}$ & $\begin{array}{c}10^{7} \\
3,400,000\end{array}$ & 5,000 & 7,000 \\
\hline E. coli & $\begin{array}{l}<1 \text { hour } \\
72 \text { hours at } 4^{\circ} \mathrm{C} .\end{array}$ & $\begin{array}{r}1,320,000 \\
945,000\end{array}$ & $\begin{array}{l}440,000 \\
410,000\end{array}$ & 5,000 & 28,000 \\
\hline ” & $\begin{array}{l}<1 \text { hour } \\
3 \text { hours at } 4^{\circ} \mathrm{C} .\end{array}$ & $\begin{array}{l}>10^{7} \\
>10^{7}\end{array}$ & $\begin{array}{l}214,000 \\
\text { Sterile }\end{array}$ & 3,000 & 5,000 \\
\hline "” " & $\begin{array}{l}<1 \text { hour } \\
<1 \text { " }\end{array}$ & $\begin{array}{l}>10^{7} \\
>10^{7}\end{array}$ & $\begin{array}{r}20 \\
25,000\end{array}$ & $\begin{array}{r}9,000 \\
100,000\end{array}$ & $\begin{array}{r}29,000 \\
119,000\end{array}$ \\
\hline " & $<1$, & & 214,000 & 223,000 & 253,000 \\
\hline
\end{tabular}

TABLE II.-In-vitro Experiment Demonstrating a Progressive Reduction in the Number of Viable Organisms After Adding Serial Dilutions of a $1: 2,000$ Solution of Chlorhexidine to a Strain of E. coll in Urine

\begin{tabular}{|c|c|c|c|c|}
\hline & \multicolumn{4}{|c|}{ Organisms $/ \mathrm{ml}$. of Urine } \\
\hline & $\begin{array}{l}\text { Control } \\
\text { Culture }\end{array}$ & $\underset{1}{\text { Culture }}$ & $\underset{2}{\text { Culture }}$ & $\underset{3}{\text { Culture }}$ \\
\hline 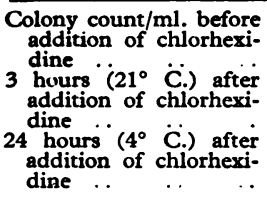 & $\begin{array}{l}3,180,000 \\
3,960,000 \\
4,190,000\end{array}$ & $\begin{array}{r}4,850,000 \\
263,000 \\
235,000\end{array}$ & $\begin{array}{r}5,100,000 \\
1,570,000 \\
1,160,000\end{array}$ & $\begin{array}{l}4,650,000 \\
3,440,000 \\
3,560,000\end{array}$ \\
\hline
\end{tabular}

Chlorhexidine dilutions: Culture $1=4 \mu \mathrm{l} . / \mathrm{ml}$. of urine. Culture $2=0.4 \mu \mathrm{l} . / \mathrm{ml}$ of urine. Culture $3=0.04 \mu \mathrm{l} . / \mathrm{ml}$. of urine. 
Fig. 1 is a graphic comparison of colony counts from suprapubic and midstream urine taken after vulval preparation with water. It can be seen that, though the midstream urine has a higher colony count in most cases, when the suprapubic count fell within the groups $10^{4}-10^{5}, 10^{5}-10^{6}, 10^{6}-10^{7}$ organisms per $\mathrm{ml}$., the midstream count was in the same group, with the exception of two counts which are near the limits of their respective groups. In 10 cases where the suprapubic specimen was sterile there were three midstream specimens with a colony count within $10^{4}-10^{5}$, and the remainder were within $10^{3}-10^{4}$.

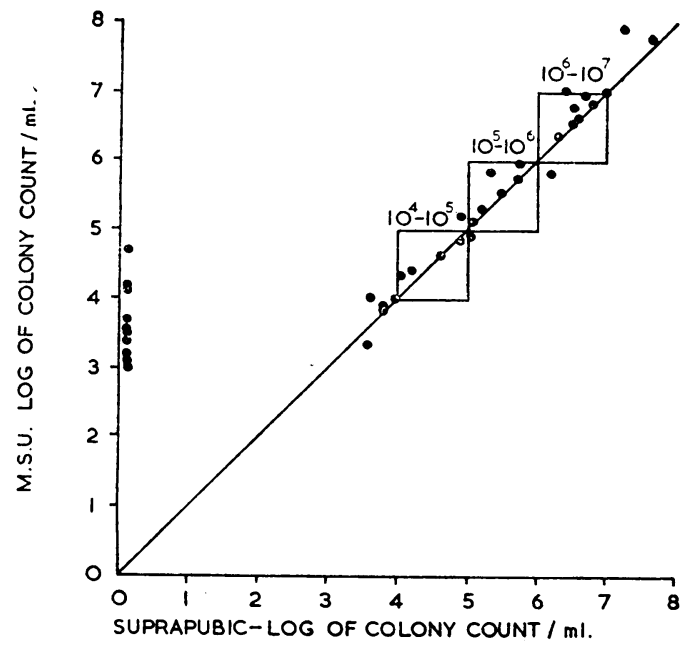

FIg. 1.-Comparison of colony counts from suprapubic and midstream urine after vulval preparation with sterile water collected within five minutes of each other. Fifty pairs of specimens, 10 pairs of which were sterile.

The effect of urinary diuresis on the colony count is shown in Table III. In all nine cases the number of organisms in the specimen taken after diuresis was reduced, the reduction varying from a visible though uncountable one to more than 40 times that of the prediuresis specimen. It is noticeable that in the five cases where both estimations were done the reduction in colony count was always greater than the accompanying reduction in urinary creatinine. Further confirmation that urinary diuresis causes an appreciable fall in the colony count is shown in Fig. 2. The dotted line indicates the marked fall in the concentration of organisms in the urine due to the diuresis when the fluid intake was $2,500 \mathrm{ml}$. from 8 a.m. to 8 p.m. Here the initial count of more than 100 million

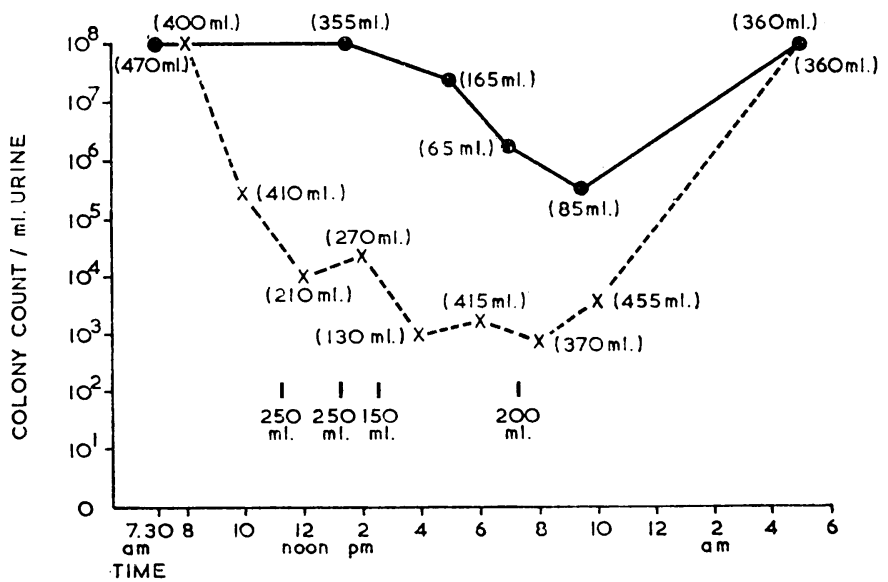

FIG. 2.-Colony counts on midstream specimens taken at each micturition over two concurrent 24-hour periods. Figures in parentheses indicate the volumes of urine passed at each micturition. The other four figures represent the volumes of fluid passed at additional micturitions when the urine was not cultured. $=$ Normal fluid intake. $\times-\cdots-\times=$ Increased intake. organisms per ml. was reduced over a period of eight hours, and after seven micturitions to 950 organisms per $\mathrm{ml}$. It is interesting that in all the patients investigated the level of infection invariably returned overnight to prediuresis levels, irrespective of whether a daytime diuresis had been induced or not, in all the patients studied. The continuous line (Fig. 2) demonstrates that the level of infection in the urine of the same patient fell during the daytime from 100 million organisms to 120,000 organisms per ml. during a normal day when the fluid intake was only $1,300 \mathrm{ml}$. This daytime reduction in the colony count when the fluid intake was normal has again been a constant feature in all the patients studied.

TABLE III.-Reduction of Colony Count Resulting from Urinary Diuresis Compared with Reduction in Urinary Creatinine Levels

\begin{tabular}{|c|c|c|c|c|}
\hline & Organism & $\begin{array}{c}\text { Concentrated } \\
\text { Suprapubic } \\
\text { Urine }\end{array}$ & $\begin{array}{c}\text { Dilute } \\
\text { Suprapubic } \\
\text { Urine }\end{array}$ & $\begin{array}{c}\text { Ratio of } \\
\text { Dilute/ } \\
\text { Concentrated } \\
\text { Suprapubic } \\
\text { Urine }\end{array}$ \\
\hline 1 Colony count $/ \mathrm{ml}$. & $\begin{array}{l}\text { Micrococcus } \\
\text { sp. }\end{array}$ & $\begin{array}{r}6,220,000 \\
196 \\
\end{array}$ & $\begin{array}{r}154,000 \\
30 \\
\end{array}$ & $\begin{array}{l}1: 40 \\
1: 6 \cdot 5 \\
\end{array}$ \\
\hline 2 Colony count $/ \mathrm{ml} . \mathrm{ml}$. & $\begin{array}{l}\text { Staph. coag. } \\
\text { neg. }\end{array}$ & $\begin{array}{r}3,260 \\
84\end{array}$ & $\begin{array}{r}420 \\
20\end{array}$ & $\begin{array}{l}1: 7 \cdot 4 \\
1: 4 \cdot 2\end{array}$ \\
\hline $\begin{array}{l}3 \text { Colony count } / \mathrm{ml} \text {. } \\
\text { Creatinine } \mathrm{mg} . / 100 \mathrm{mi} .\end{array}$ & E. coli & $\begin{array}{r}>10^{7} \\
196\end{array}$ & $\begin{array}{r}730,000 \\
118\end{array}$ & $\begin{array}{r}>1: 13 \\
1: 1 \cdot 7\end{array}$ \\
\hline $\begin{array}{l}\text { Colony count } / \mathrm{ml} \text {. } \\
\text { Creatinine } \mathrm{mg} . / 100 \mathrm{ml} \text {. }\end{array}$ & $"$, & $\begin{array}{r}5,020,000 \\
25 \\
\end{array}$ & $\begin{array}{r}527,000 \\
14 \\
\end{array}$ & $\begin{array}{l}1: 9 \cdot 5 \\
1: 1 \cdot 8 \\
\end{array}$ \\
\hline 5 Colony count $/ \mathrm{ml}$. & Proteus sp. & $\begin{array}{r}6,100 \\
29 \cdot 5 \\
\end{array}$ & $\begin{array}{l}450 \\
12 \cdot 5\end{array}$ & $\begin{array}{l}1: 13 \\
1: 2 \cdot 4 \\
\end{array}$ \\
\hline $\begin{array}{l}6 \text { Colony count } / \mathrm{ml} . \\
\text { Creatinine } \mathrm{mg} . / 100 \mathrm{mi} .\end{array}$ & Str. faecalis & $>10^{7}$ & 420,000 & $1: 24$ \\
\hline $\begin{array}{l}7 \text { Colony count } / \mathrm{ml} . \\
\text { Creatinine } \mathrm{mg} . / 100 \mathrm{ml} .\end{array}$ & Micrococcus & $\begin{array}{l}>10^{7} \\
85\end{array}$ & $\begin{array}{c}10^{7} \text { (reduced) } \\
40\end{array}$ & $1 \div 2 \cdot 1$ \\
\hline 8 Colony count $/ \mathrm{ml}$. & Klebsiella & $\begin{array}{l}>10^{2} \\
160\end{array}$ & $\begin{array}{c}10^{7} \text { (reduced) } \\
94\end{array}$ & $\overline{1: 1 \cdot 8}$ \\
\hline 9 Colony count $/ \mathrm{ml} .9 \mathrm{ml}$. & E. coli & $>10^{7}$ & $10^{7}$ (reduced) & $\overline{-}$ \\
\hline
\end{tabular}

\section{Discussion}

That vulval preparation with an antiseptic such as chlorhexidine by ward staff before the collection of a midstream urine may affect the quantitative assessment of bacterial growth in urine has been clearly confirmed in this study. The importance of this observation is evident from a random survey of the literature shown in Table IV, from which it can be seen that in 12 out of 21 English-language publications some form of vulval preparation which might interfere with bacterial growth had been referred to. Kass (1965) recommends preparation of the vulva with soap, while Turner (1961) thinks that no prior cleansing is necessary. Statements on the bacteriological accuracy of urine collection procedures, until the introduction of the suprapubic technique for collecting urine, have depended on population studies, which are not altogether satisfactory, as they fail to indicate the frequency of false-positives and falsenegatives, which may cancel each other out in using this last sort of comparison.

TABle IV.-Fluid Used for Vulval Preparation Before Collection of Midstream Urine in 21 Studies Taken at Random from the Literature None Soap solution Chlorhexidine (Hibitane) Benzalkonium chloride (Roccal, Zephiran) $\begin{array}{lllll} & \ldots & \ldots & 4\end{array}$ Hexachlorophane, (Phisohex), domiphen bromide (Bradosol),

In this study on women it was decided to use some form of vulval cleansing, since vaginal discharge or lochia may considerably contaminate midstream urine in the unprepared patient (Beard et al., 1965). Sterile water has been used, as this is readily available in hospital, but it must be admitted that tap-water would probably be as suitable. The results shown in Fig. 1, where colony counts from suprapubic and midstream 
specimens are compared, show that this form of vulval preparation is satisfactory at all levels of bacteriuria, and avoids the bacterial inhibition which may result if an antiseptic solution is used. This evidence is of particular value to the clinician when it is considered that the specimens were collected by an unselected group of nurses.

The evidence presented shows that both diuresis and time of day when the specimen is taken may considerably affect the bacterial colony count. Though Stamey et al. (1965) doubted whether hydration could reduce the colony count below 1,000 organisms per ml., this had occurred in several of our cases, and this has also been reported by Goldberg et al. (1965). O'Grady and Cattell (1966) and O'Grady and Pennington (1966) have shown in vivo and in vitro that the initial reduction is usually maximal shortly after the start of diuresis and gradually becomes less obvious with succeeding micturitions. It is likely that the greater reduction in the level of bacteriuria as compared with the creatinine concentration in the dilution studies may be due to the additional effect of an increase in the frequency of micturition, as suggested by Cox and Hinman (1961). The increased frequency of micturition during the day may also account for the reduction in the colony count at this time. This effect and that of diuresis have an obvious practical application, since they may increase the problem of diagnosis of urine infection. Thus a patient with a colony count of 100,000 organisms per ml. in an early morning specimen of urine could have a colony count reduced to below 1,000 organisms per $\mathrm{ml}$. if the specimen had been collected later in the day or when the patient was well hydrated.

In all the seven patients studied over four days who had an asymptomatic bacteriuria similar to the case shown in Fig. 2 the early morning specimen had the highest level of infection. Fig. 2 shows that even after a day of hydration the level of bacteriuria in the early morning specimen exceeded 100 million organisms per $\mathrm{ml}$. It is also apparent during the day that in general the longer the time interval between each micturition the higher the colony count is likely to be. From this evidence it is advisable that, when possible, urine passed on waking in the morning should be used for diagnostic purposes. If this is not possible, at least two hours should have been allowed to elapse since the previous micturition before collecting the specimen. The practice of instructing patients who have recently micturated to drink large amounts of fluid in order to save time before taking a midstream specimen should be avoided.

\section{Summary}

Vulval cleansing with a $1: 2,000$ solution of chlorhexidine (Hibitane) has been shown to result of ten in a marked reduction in the bacterial colony count of midstream urine. Cleansing with sterile water has been shown to provide a satisfactory alternative for this procedure.

Urinary diuresis greatly reduces the colony count of infected urine.

The early morning specimen of urine constantly has the highest level of infection, and this gradually declines during the day.

We are grateful to Professor S. G. Clayton for allowing us to study patients under his care, and to the nursing staff on 4th East Ward and in the outpatient department for their assistance in collecting the midstream specimens of urine.

REFERENCES

Beard, R. W., McCoy, D. R., Newton, J. R., and Clayton, S. G. (1965). Lancet, $2,610$.

Bradley, J. M., and Little, P. J. (1963). Brit. med. f., 2, 361.

Cox, C. E., and Hinman, F. (1961). F. Urol. (Baltimore), 86, 739.

Folin, O., and Doisy, E. A. (1917). \%. biol. Chem., 28, 349.

Goldberg, L. M., Vost, K. L., and Rantz, L. A.' (1965). Progress in Pyelonephritis, edited by E. H. Kass. Oxcord.

Kass, E. H. (1957). Arch. intern. Med., 100, 709.

(1962). Lancet, 1, 46.

(1965). Technical Bulletin A, personal communication.

Marple, C. D., (1941). Ann. intern. Med., 14, 2220.

O'Grady, F., and Cattell, W. R. (1966). Brit. F. Urol., 38, 156.

O'Grady, F., and Cattell, W. R. (1966). Brit. F. exp. Path., 47, 152.

Stamey, T. A., Govan, D. E., and Palmer, J. M. (1965). Medicine (Baltimore), 44, 1.

Turner, G. C. (1961). Lancet, 2, 1062.

Wood, E. C., Pinkerton, J. H. M., and Calman, R. M. (1960). Brit. med. f., 1, 961 .

\title{
Synchronized Micturition and Antibiotic Administration in Treatment of Urinary Infection in an In Vitro Model
}

\author{
FRANCIS O'GRADY,* M.D., M.SC., M.C.PATH. ; J. H. PENNINGTON,† M.A., M.D.
}

\author{
Brit. med. F., 1967, 1, 403-406
}

In laboratory estimations of the minimum inhibitory concentration of antibacterial agents it is common practice to make dilutions of the agent and to seed them with a fluid culture of the organism in such a way that the fully grown culture is diluted at least a hundredfold. The concentration of antibacterial agent required to inhibit bacterial growth commonly increases if the concentration of bacteria against which it is tested is increased (Garrod, 1958). Fully grown cultures may not be affected by concentrations of agent greatly in excess of that necessary to inhibit dilute cultures. Infected urine commonly constitutes a fully or near fully grown culture, and it is possible that the effect of an antibacterial agent on such urine may be very much less than anticipated from testing the

\footnotetext{
* Reader in Bacteriology, St. Bartholomew's Hospital, London. † Lecturer in Bacteriology, St. Bartholomew's Hospital, London.
}

agent in vitro against diluted cultures of the organism. It follows that antibacterial agents excreted into the urine when the bladder is already partly filled with infected urine will be discarded when the bladder is next emptied, having exerted little effect.

Relatively little dilution often sharply reduces the resistance of a fully grown culture to an antibacterial agent (O'Grady and Cattell, 1966). When infection is confined to the bladder the infected bladder urine is continuously diluted by the ingress of sterile ureteric urine, and this dilution effect is maximum immediately after micturition. Substantially better therapeutic results might therefore be obtained if drug administration and micturition were so synchronized that the drug reached its maximum concentration in urine immediately after the bladder was emptied, when the remaining infected urine was subjected to the greatest diluting effect of ureteric urine. 